\title{
Nexus of Foreign Direct Investment, Domestic Investment, and Manufacturing Industry Value Added in Indonesia
}

\author{
Horas Djulius ${ }^{1}$, Choi Wongyu², Juanim³ ${ }^{3}$ Raeni Dwi Santy ${ }^{4}$
}

\begin{abstract}
The development of the manufacturing industry is one of the standards for Indonesia's development as a developing country. Domestic investment (DI) and foreign direct investment (FDI) can meet investment needs in this industry. This paper focuses on the nexus of the two types of investment in meeting investment needs in the manufacturing industry and the influence of those investments in relatively capital-intensive and relatively labor-intensive industrial groups. The aim is to evaluate the role of both types of investments and their benefits to the economy not only to the value-added but also in transferring technology and knowledge spillover from FDI to DI. The panel data regression was first to do to observe the differences between groups of relatively capital-intensive industrial samples and relatively labor-intensive industrial samples. The comparison results show that there are significant differences between the two industry groups so that it can be regressed on these two sample types, apart from the regression of the overall sample. The overall sample found that both FDI and DI influence the value-added of the manufacturing industry.
\end{abstract}

Keywords: foreign direct investment; domestic direct investment; manufacturing value-added

\begin{abstract}
Abstrak
Perkembangan industri manufaktur merupakan salah satu tolok ukur pembangunan Indonesia sebagai negara berkembang. Kebutuhan investasi dalam industri ini dapat dipenuhi dari investasi domestik (ID) dan investasi asing langsung (IAL). Tulisan ini berfokus pada keterkaitan dari kedua jenis investasi tersebut dalam memenuhi kebutuhan investasi pada industri manufaktur. Pengaruh kedua jenis investasi itu juga diuji dalam kelompok industri yang relatif padat kapital dan relatif padat tenaga kerja. Tujuannya agar diketahui apakah keduanya telah memainkan peran masing-masing dan dapat memberikan benefit terhadap perekonomian bukan hanya dalam menghasilkan nilai tambah tetapi juga transfer teknologi investasi asing langsung kepada investasi domestik. Pertama-tama dilakukan regresi data panel untuk melihat apakah terdapat perbedaan antara kelompok sampel industri yang relatif padat kapital, dengan, sampel industri yang relatif padat tenaga kerja. Hasil perbandingan menyatakan bahwa ada perbedaan yang signifikan diantara dua kelompok industri sehingga dapat dilakukan regresi terhadap kedua jenis sampel ini, selain dari regresi terhadap sampel keseluruhan. Pada sampel keseluruhan ditemukan pengaruh bersama IAL dan ID terhadap nilai tambah industri manufaktur.
\end{abstract}

Kata Kunci: investasi asing langsung; investasi domestik; nilai tambah industri manufaktur

\section{How to Cite:}

Djulius, H, Wongyu, C, Juanim, \& Santy, R. D. (2019). Nexus of Foreign Direct Investment, Domestic Investment, and Manufacturing Industry: Value Added in Indonesia. Signifikan: Jurnal Ilmu Ekonomi. Vol. 8 (1): 1 - 8. doi: http://dx.doi.org/10.15408/sjie.v8i1.9520. 


\section{Introduction}

In many countries, the manufacturing industry is an important sector to sustain the national economic development, and its important role is to create value-added product by utilizing natural resources to be processed into high-value items. Developing the sectors of the manufacturing industry with the innovation and application of advanced technology is still a problem. Indonesia is one of the countries that utilize the manufacturing industry sector into one of the sources of economic growth that obtain many workers. Data from the Ministry of Industry in 2015 elucidate that the industrial sector, particularly the non-oil and gas-manufacturing sector, had significant growth, surpassing the GDP growth of Indonesia in the first quarter of 2015. The rapid growth rate in this industry is the impact of the high investment of the previous period. As in 2010, the investment trend of the industrial sector in Indonesia has continued to increase despite being halted due to the financial crisis in 2008 (Tambunan, 2010). Industrial developments in developing countries are critical in reducing poverty and achieving sustainable economic growth, especially export-oriented and laborintensive industries, which will create revenues and provide employment (Abdul, 2010).

The development of the manufacturing industry requires investment, which can come from domestic and abroad. The options are mainly from foreign direct investment (FDI) or domestic direct investment (DI). In many countries, FDI has a positive impact on industry value-added through knowledge spillover, knowledge management, and increased labor productivity. In this case, government policy plays an important role in channeling FDI into the proper direction to allow for benefits from positive externalities as well as absorption capacities of local firms (Azarhoushang et al., 2015). Moreover, FDI has positively contributed to the value-added of the Indonesian economy. One main channel for the positive effect is that foreign companies generate higher value-added than domestic firms. FDI can also increase the value-added in domestic companies in the same industry or province. The high value-added in foreign firms along with positive externalities on domestic firms ultimately has a positive impact on the Indonesian economy.

FDI will also contribute to structural change in the economy, which increases the value-added and the standard of living by moving resources from low value-added sectors to high value-added sectors (Sjöholm, 2016). A positive and significant influence exists from FDI on industrial sector growth; particularly in high-skilled industries and dependent on external capital (Alfaro \& Charlton, 2007). FDI is expected to increase the invested resources and, importantly, to improve the technological standards, efficiency, and competitiveness of domestic industries (Fatima, 2016). Nevertheless, DI is also required to make development financing less dependent on other countries. The relationship between FDI and DI is likely to be bi-directional, with FDI inflows that also affect the factor market (Agosin \& Machado, 2005; UNCTAD, 2013) .

FDI and DI can complement or substitute each other's role in improving economic growth. In a country where FDI has a short-term substitute relationship with DI when FDI has an influence on economic growth, DI usually has no such influence and vice versa. Nevertheless, FDI, DI, and economic growth are co-integrated in the long term (Lean et 
al., 2011). In a country where FDI has a complementary relationship with DI, FDI helps overcome a lack of capital and can stimulate economic growth through DI (Amighini et al., 2015). Even in the case of developing countries, DI can stimulate FDI, where DI can be a good predictor of future investment flows (Lauter \& Moreaub, 2012).

This study focuses on the role of FDI and DI on the value-added of manufacturing industries. There is an in-depth explanation of both roles in manufacturing industries that are relatively capital intensive or labor intensive. Thus this research will contribute to policy recommendations in bringing in FDI and DI into the country, especially in the manufacturing industry.

\section{Methods}

The data used are secondary data from Statistics Indonesia and Indonesia's Investment Coordinating Board from 2010 to 2015. The value-added variable is the amount of output minus the amount of input value (intermediate cost) produced by the manufacturing industry, which is registered by the Central Statistics Agency, in millions of rupiah per year. The FDI variable is the foreign inflow investment recorded by the World Bank in millions of rupiah per year. The DI variable is the realization of domestic direct investment registered by Indonesia's Investment Coordinating Board in millions of rupiah per year.

Indonesia's Investment Coordinating Board established the classification of the manufacturing industry that follows the classification of the investment sector, both FDI and DI. Therefore, there is an industry classification adjustment for the value-added variables from Statistic Indonesia by merging sub-sectors that have a similar classification. Consequently, 10 available industry classifications are food industry; textile industry; leather goods and footwear industry; wood industry; paper and printing industry; pharmaceutical industry; rubber and plastic industry; non-metallic mineral industry; metal, machinery, and electronic industry; and motor vehicles and other transport equipment industry.

The classification of factor intensity is from the calculation of the share of labor expenditure and the share of capital costs to industrial output. According to this formula, the capital-intensive industry group are food industry, paper and printing industry, the pharmaceutical industry, and non-metallic mineral industry, whereas the other 6 industries are the labor-intensive industry group.

The econometric model used is as follows:

$V A_{i t}=\alpha+\beta_{1} F D I_{i t}+\beta_{2} D I_{i t}+\varepsilon_{i t}$

where: VA is value added; FDI is foreign direct investment; DI is domestic investment.

Equation (1) is estimated by panel data regression with several possible methods, i.e., pooled least squares, fixed effect model, or random effect model. To select a highly suitable method, the Chow and Haussmann tests were first performed. Then the Chow test to examine the difference of investment impact on value-added in the "Overall Sample" group with the "Capital Intensive" and "Labor Intensive" groups. The Haussmann test was done to determine whether the fixed effect or the random effect model will be selected as a panel data analysis method. 


\section{Result and Discussion}

Modeling using common effect model was conducted with the regression of panel data for these three groups: overall data, capital-intensive sample, and labor-intensive sample. The estimation results shows in Table 1.

Table 1. Common intercept

\begin{tabular}{cccc}
\hline Number & Variable & Regression Coefficient & p-value \\
\hline 1 & Intercept & 28234.25 & 0.06 \\
2 & FDI & 57.17 & 0.00 \\
3 & DI & 8.91 & 0.00 \\
\hline
\end{tabular}

$R^{2}=0.61 ;$ F stat $=45.02 ;$ Prob $=0.00$

Source: data processing

The Chow test procedure produced an F-statistic value of 2.18. This means that there are differences in the regression results between overall data, capital-intensive groups, and labor-intensive groups. The Haussmann test on the overall data group with capital-intensive and labor-intensive samples was done to determine if the fixed effect or random effect model is selected. The Haussmann result shows in Table 2.

Table 2. Haussmann test

\begin{tabular}{cccc}
\hline No & Group & Chi-Sq. Statistic & p-value \\
\hline 1 & overall data & 4.86 & 0.08 \\
2 & capital intensive sample & 4.64 & 0.09 \\
3 & labor intensive sample & 7.64 & 0.02 \\
\hline
\end{tabular}

Source: data processing

Based on the Hausman test in Table 2, the method for the overall data and the capitalintensive group is the random effect model, whereas the fixed effect model is in the laborintensive sample. Table 3 shows the statistical summary of the effects of FDI and DI on value-added. The sample groups are overall data, capital-intensive group, and labor-intensive group. 
Table 3. Static Equation Estimation

\begin{tabular}{|c|c|c|}
\hline \multicolumn{3}{|l|}{$\begin{array}{l}\text { Overall Data } \\
\text { Random Effect Model }\end{array}$} \\
\hline Variable & Regression Coefficient & $\mathrm{p}$-value \\
\hline Intercept & 62323.80 & 0.00 \\
\hline FDI & 28.11 & 0.00 \\
\hline DI & 8.13 & 0.00 \\
\hline \multicolumn{3}{|c|}{$R^{2}=0.44 ; F$ stat $=22.16$, Prob $=0.00$} \\
\hline \multicolumn{3}{|c|}{$\begin{array}{l}\text { Capital Intensive Group } \\
\text { Random Effect Model }\end{array}$} \\
\hline Variable & Regression Coefficient & $\mathrm{p}$-value \\
\hline Intercept & 52432.15 & 0.01 \\
\hline FDI & 27.75 & 0.14 \\
\hline DI & 8.46 & 0.00 \\
\hline \multicolumn{3}{|c|}{$R^{2}=0.43 ; F$ stat $=8.07$, Prob $=0.00$} \\
\hline \multicolumn{3}{|l|}{$\begin{array}{l}\text { Labor Intensive Group } \\
\text { Fixed Effect Model }\end{array}$} \\
\hline Variable & Regression Coefficient & $\mathrm{p}$-value \\
\hline Intercept & 72875.31 & 0.00 \\
\hline FDI & 22.78 & 0.07 \\
\hline DI & 7.478 & 0.21 \\
\hline
\end{tabular}

Source: data processing

The first part of Table 3 shows that FDI and DI affect the value-added of the manufacturing industry for the overall sample. All predictors have a significant influence although the coefficient of determination is less than $50 \%$. The next section shows that, for the capital-intensive group, only the domestic investment significantly influences valueadded, whereas FDI has insignificant influence. The previous section shows an inconsiderable difference. The statistics on the capital-intensive group shows the coefficient of determination, which is also below $50 \%$. The last part of Table 3 shows the estimation results for the laborintensive group. Contrary to the results of the capital-intensive group, FDI has a significant influence on value-added. In addition, at the end of Table 3, the coefficient of determination is $87 \%$. The estimation result on the overall and labor-intensive samples corroborates that FDI has a positive and significant influence on value-added. In the capital-intensive group, FDI has a positive but insignificant effect on the value-added of the manufacturing industry sector. Therefore, there are differences in outcomes between industry groups incorporated 
in capital-intensive and labor-intensive samples. The diversity of these results also occurs in other developing countries, where FDI has a positive and negative impact on valueadded, especially in the long run (Akpan \& Eweke, 2017; Chandran \& Krishnan, 2008; Uwubanmwen \& Ogiemudia, 2016)

The effects of FDI on the economic performance and manufacturing sectors can attract several foreign investors. Domestic companies will benefit from getting spillover in the form of knowledge, technology, innovation ability, marketing, and their management skills due to foreign companies from FDI (Djulius, 2017). Knowledge spillover is also likely to result in increased productivity in the manufacturing industry.

The domestic investment shows a significant influence on industrial value-added in the overall and capital-intensive samples, whereas DI has no significant effect on the laborintensive sample. These results verify that domestic investment is considered influential in increasing the value-added of capital-intensive manufacturing industries, such as chemical, food, mineral, and paper industries, whereas FDI is highly influential in labor-intensive manufacturing industries, such as metal, motor, rubber, cloth, leather, and wood. Moreover, FDI is able to boost domestic investment because of a close relationship between the two investments (Ilyas et al., 2010; Morrissey \& Udomkerdmongkol, 2012; Wang, 2010)

In certain developed countries, there is also a significant relationship between FDI and domestic investment in all industries that complement domestic capital formation. Evidence shows that government policy in the industrial sector can improve the profitability and scope of DI and will be effective in increasing FDI inflows in developing countries.

The effect of FDI on value-added is only significant in the manufacturing industry, which has a high labor intensity factor. Hence, foreign investors still consider labor cost in choosing their host country, including Indonesia. For Indonesia, it is important to note that the labor cost can no longer be a comparative advantage in attracting FDI in the long run. Other developing countries that have a workforce willing to be paid less than that of the labor cost in Indonesia will emerge. In the future, the relationship between FDI and DI hopefully complement each other in labor-intensive and capital-intensive industries.

\section{Conclusion}

Foreign direct investment and domestic direct investment both influence the valueadded of manufacturing industries in Indonesia, which means there are complementary effects between the two types of investment. Only domestic investment has significant influence in a relatively capital-intensive industrial group. In contrast, only foreign direct investment has a significant influence in a relatively labor-intensive group. This demonstrates that foreign direct investment is still more attractive to relatively inexpensive industries.

The government can provide more incentives to FDI that invest in a more dense industry to enlarge the impact of technology transfer and knowledge spillover. At the same time, strengthening domestic investment is required in order to have the absorption and adoption of technology transfers from FDI. This study has limitations in the grouping of capital-intensive and labor-intensive industries in term of a comparison of the number of 
workers and the capital value. A more detailed grouping using other methods can improve the results of research on the nexus between FDI and DI in the manufacturing industry in Indonesia.

\section{Acknowledgment}

Authors are grateful to Directorate of Research and Community Service, Directorate General of Research and Development Reinforcement, Ministry of Research, Technology and Higher Education, Republic of Indonesia that has funded this collaboration research

\section{References}

Abdul, K. (2010). Determinants of Foreign Direct Investment in Developing Countries : A Comparative Analysis. The Journal of Applied Economic Research, 4(4), 369-404.

Agosin, M. R., \& Machado, R. (2005). Foreign Investment in Developing Countries: Does it Crowd in Domestic Investment? Oxford Development Studies, 33(2), 149-162.

Akpan, E. S., \& Eweke, G. O. (2017). Foreign Direct Investment and Industrial Sector Performance: Assessing the Long-Run Implication on Economic Growth in Nigeria. Journal of Mathematical Finance, 7(2), 391-411.

Alfaro, L., \& Charlton, A. (2007). Growth and the Quality of Foreign Direct Investment. In The Industrial Policy Revolution I (pp. 162-204).

Amighini, A. A., Mcmillan, M., \& Sanfilippo, M. (2015). FDI as a Catalyst for Domestic Investment in Developing Economies: New Evidence from Industry-level Data. Società Italiana degli Economisti.

Azarhoushang, B., Masoumy, P., \& Wu, J. P. (2015). FDI Effects on Industrial Value-added: Evidence from Chinese and Thai Government Policies. ETSG Paris Working Paper.

Chandran, V. G. R., \& Krishnan, G. (2008). Foreign Direct Investment and Manufacturing Growth : The Malaysian Experience. International Business Research, 1(3), 83-90.

Djulius, H. (2017). Foreign Direct Investment and Technology Transfer: Knowledge Spillover in the Manufacturing Sector in Indonesia. Global Business Review, 18(1), 57-70.

Fatima, S. T. (2016). Productivity spillovers from Foreign Direct Investment: Evidence from Turkish Micro-level Data. The Journal of International Trade \& Economic Development, 25(3), 291-324.

Ilyas, M., Ahmad, H. K., Afzal, M., \& Mahmood, T. (2010). Determinants of Manufacturing Value added in Pakistan: an Application of Bounds Testing Approach to Cointegration. Pakistan Economic and Social Review, 48(2), 209-224.

Lauter, M., \& Moreaub, F. (2012). Domestic Investment and FDI in Developing Countries : The Missing Link. Journal Of Economic Development, 37(3), 1-23.

Lean, Hooi Hooi and Tan, B. W. (2011). Linkages between Foreign Direct Investment, Domestic Investment and Economic Growth in Malaysia. Journal of Economic Cooperation and Development, 32(4), 75-96. 
Morrissey, O., \& Udomkerdmongkol, M. (2012). Governance, Private Investment and Foreign Direct Investment in Developing Countries. World Development, 40(3), 437445.

Sjöholm, F. (2016). Foreign Direct Investment and Value Added in Indonesia. IFN Working Paper No. 1141, 2016.

Tambunan, T. T. H. (2010). The Indonesian Experience with Two Big Economic Crises. Modern Economy, 01(03), 156-167.

United Nations Conference on Trande and Development [UNCTAD]. (2013). Strengthening Linkages Between Domestic and Foreign Direct Investment in Africa. UNCTAD Working Paper TD/B/EX(57)/3. retrieved from: https://unctad.org/meetings/en/ SessionalDocuments/tdbex $57 \mathrm{~d} 3$ _en.pdf.

Uwubanmwen, A. E., \& Ogiemudia, O. A. (2016). Foreign Direct Investment and Economic Growth : Evidence from Nigeria. International Journal of Business and Social Science, 7(3), 89-103.

Wang, M. (2010). Foreign Direct Investment and Domestic Investment in The Host Country: Evidence from Panel Study. Applied Economics, 42(29), 3711-3721. 